Article

\title{
Performance and Yeast Tracking in A Full-Scale Oil-Containing Paromomycin Production Wastewater Treatment System Using Yeast
}

\author{
Chunyan Wang ${ }^{1,2}$, Ran Ding ${ }^{1}$, Yingxin Gao ${ }^{1,3}$, Min Yang ${ }^{1,3}$ and Yu Zhang ${ }^{1,3, *}$ \\ 1 State Key Laboratory of Environmental Aquatic Chemistry, Research Center for Eco-Environmental Sciences, \\ Chinese Academy of Sciences, Beijing 100085, China; wggbb@163.com (C.W.); randing@rcees.ac.cn (R.D.) \\ 2 Department of Biology and Chemical Engineering, Nanyang Institute of Technology, Nanyang 473004, China \\ 3 University of Chinese Academy of Sciences, Beijing 100049, China; gyx@rcees.ac.cn (Y.G.); \\ yangmin@rcees.ac.cn (M.Y.) \\ * Correspondence: zhangyu@rcees.ac.cn; Tel.: +86-10-6291-9883
}

Academic Editors: Gabriele Freni and Gaetano Di Bella

Received: 14 February 2017; Accepted: 19 April 2017; Published: 22 April 2017

\begin{abstract}
High residual oil content in antibiotic production waste mother liquor makes solid-liquid separation of fermentation residue and wastewater difficult. A yeast-based pretreatment process was established for the removal of oil and promotion of solid-liquid separation in antibiotic production wastewater treatment systems. Six yeast strains acquired from different sources were inoculated into sequencing batch reactors (SBR) in pilot and full-scale wastewater treatment plants. Oil removal rates were $85.0 \%-92.0 \%$ and $61.4 \%-74.2 \%$, and sludge settling velocities (SV) were $16.6 \%-21.3 \%$ and $22.6 \%-32.0 \%$ for the pilot and full-scale operations, respectively. $18 \mathrm{~S}$ rRNA gene clone libraries were established to track the fates of the inoculated yeasts, which showed that Candida tropicalis was dominant in the full-scale plant. The fungi and bacteria gene copy ratio determined by quantitative polymerase chain reaction was 14.87 during stable field operation, indicating that yeast successfully colonized. Both the pilot and full-scale studies proved that yeast can be used to promote solid-liquid separation, and yeast systems are a stable and effective method for oil-containing fermentation antibiotic production wastewater pretreatment.
\end{abstract}

Keywords: fermentation antibiotic production wastewater; pretreatment system; yeast

\section{Introduction}

Antibiotic production methods consist of microorganism fermentation, as well as chemical and half-chemical synthesis. Currently, most antibiotics in use, such as aminoglycosides, are produced by microbial fermentation. Production processes are roughly divided into fermentation, filtration, extraction, and refinement. The main pollutants are waste mother liquor and fermented residue. Waste mother liquor commonly contains substrates (e.g., oil, starch, cellulose, polysaccharides), target products (e.g., antibiotics), by-products (e.g., glyoxylate), and extraction solvents [1,2]. To produce aminoglycosides (such as paromomycin and ribostamycin), soybean oil is widely used in the fermentative substrate as a high-quality carbon source, oxygen vector, and antifoam compound. However, high soybean oil content can lead to difficulties in wastewater treatment and solid-liquid separation of fermentation residue and wastewater. Thus, fermentative antibiotic production waste mother liquor is characterized by high concentrations of oil, chemical oxygen demand (COD), and suspended solids (SS), as well as poor settling velocity (SV), which are major issues in antibiotic production wastewater treatment [3]. Thus, pretreatment technology research has become critical.

Some limited research has been conducted on suitable methods to pretreat antibiotic fermentation wastewater [4-6]. Compared to physical-chemical methods, biological processes are economical 
and effective [7]. However, for conventional bacteria-based activated sludge systems, antibiotic fermentation wastewater contains residual fermentation media, antibiotics, and other toxic compounds, which can severely inhibit microbial activities [8]. Furthermore, antibiotic resistance genes are more likely to be acquired due to high levels of residual antibiotics and bacterial densities in traditional biological treatment systems of antibiotic production wastewater $[9,10]$. Therefore, bio-augmentation strategies might be a viable alternative, and include specific microbial biomass with high tolerance to toxicants and capacity for the specific degradation of target substrates [11].

Yeasts are a group of unicellular fungi that show high tolerance to low $\mathrm{pH}$, high salinity, high organic content, antibiotics, and sterilizers [12], and can metabolize various carbon substrates $[13,14]$. A wide spectrum of different yeasts can grow well on lipids, which have good oil uptake rates and higher growth rates in oil-rich wastewater environments $[15,16]$. Many studies and industrial practices have found the application of yeast isolates in the treatment of high-strength oil-containing wastewater to be very promising [17-19]. Yeast treatment processes are suitable and cost-effective for the treatment of oil-rich industrial wastewater that cannot be treated by conventional biological methods directly [20]. Oil-rich wastewater treated by yeast is released mainly from slaughterhouses and tanneries, as well as dairy and oil food processing industries, but little information is available regarding the treatment of oil-containing antibiotic production wastewater by yeast. Our previous study revealed for the first time that many key functional genes of fungi involved in carbon degradation in activated sludge are enhanced under high levels of antibiotics [21], showing the considerable potential of yeast for the pretreatment of antibiotic production wastewater. It is speculated, therefore, that yeast technology could be used in the pretreatment of oil-containing fermentation antibiotic production wastewater.

The aim of the present study was to investigate the feasibility of isolated yeast as an effective method for pretreating fermentation antibiotic production waste mother liquor in pilot and full-scale systems. The target antibiotic wastewater was paromomycin fermentation waste mother liquor with high oil content and fermentation residue. Both quantitative polymerase chain reaction (qPCR) and fungi $18 \mathrm{~S}$ rRNA gene clone libraries were used to track inoculated yeasts during treatment. This paper confirmed the feasibility of employing fungi in antibiotic production wastewater pretreatment.

\section{Materials and Methods}

\subsection{Yeast Strains and Cultivation}

As shown in Table 1, all used strains except Yarrowia lipolytica were isolated and identified in our previous study. Yarrowia lipolytica strain (CGMCC 2.1207) is purchased from the China General Microbiological Culture Collection Center (CGMCC), who was clearly identified by CGMCC and studied further by Lv, W.Z. [22]. Pichia anomala (CGMCC 2.4177) strain was isolated from oily soil samples collected from Jidong Oilfield in Hebei Province, China, and identified by analysis of $18 \mathrm{~S}$ and $26 \mathrm{~S}$ ribosomal DNA sequences [23]. The remainders Candida tropicalis (CGMCC 2.2158), Candida boidinii (CGMCC 2.2162), Trichosporon asahii (CGMCC 2.2164), and Williopsis saturnus (CGMCC 2.2165) were isolated from soil samples contaminated salad oil wastewater and identified based on morphological and biochemical characteristics [24]. All used yeast strains were preserved with YPD media (1\% yeast extract, $2 \%$ peptone, $2 \%$ dextrose, $\mathrm{pH} 5.5$ ) at $-80{ }^{\circ} \mathrm{C}$.

Each yeast glycerol stock was inoculated individually into a $250 \mathrm{~mL}$ flask containing $100 \mathrm{~mL}$ YPD media, and cultured at $28^{\circ} \mathrm{C}$ and $120 \mathrm{rpm}$ for $48 \mathrm{~h}$. Sub-culturing was conducted twice in the same conditions with $10 \mathrm{~mL}$ inoculum from the previous culture. The pre-cultures were prepared well when the optical density (OD) of cells reached $0.8-1$. All pre-cultures were equally $(50 \mathrm{~mL})$ transferred into a 20-L biomass cultivation tank, and cultivated aerobically for 10 days under fill-and-draw mode with $5 \mathrm{~L}$ of fresh medium changed daily. The medium contained $5 \mathrm{~g}$ of glucose, $4 \mathrm{~g}$ of $\mathrm{NH}_{4} \mathrm{Cl}, 0.4 \mathrm{~g}$ of $\mathrm{NaH}_{2} \mathrm{PO}_{4} \cdot 2 \mathrm{H}_{2} \mathrm{O}$, and $1000 \mathrm{~mL}$ of distilled water, pH 5-6, supplemented with $2 \mathrm{~mL}$ of unsterilized soybean oil. At the end of the cultivation, the yeast mixture was centrifuged and washed by aseptic 
physiological saline three times to remove the organic matters absorbed on yeasts. The mixed liquid suspended solids (MLSSs) of the mixture were measured to be $832 \mathrm{mg} / \mathrm{L}$. The yeast mixture was preserved with aseptic physiological saline at $4{ }^{\circ} \mathrm{C}$, and used as the inoculum in follow-up tests.

Table 1. Information on inoculated yeast strains.

\begin{tabular}{ccc}
\hline Inoculation Strains & Registration Number & Sample Source \\
\hline Candida tropicalis & CGMCC 2.2158 & \\
Candida boidinii & CGMCC 2.2162 & Salad oil-manufacturing factory \\
Trichosporon asahii & CGMCC 2.2164 & \\
Williopsis saturnus & CGMCC 2.2165 & \\
Pichia anomala & CGMCC 2.4177 & Oil contaminated soil samples \\
Yarrowia lipolytica & CGMCC 2.1207 & China General Microbiological \\
& & Culture Collection Center \\
\hline
\end{tabular}

\subsection{Description of Pilot and Full-scale Systems}

The pre-experiment for antibiotic production wastewater directly treated without yeast mixture was conducted by intermittent aeration for two weeks. Oil content and SV were randomly detected to evaluate the action of indigenous microbe in wastewater.

The pilot test was carried out in an SBR with a working volume of $20 \mathrm{~L}$ using the acquired yeast mixtures and paromomycin production waste mother liquor. The reactor system consisted of a feed pump, reactor, effluent pump, effluent bottle, and wet gas meter. The experiments of optimum operating conditions were conducted in the pilot-scale system. Hydraulic retention time (HRT), as the most important parameter that could affect the processing effect, was optimized by detecting the daily soluble chemical oxygen demand (SCOD) removal rate and sludge settling velocity (SV) during the aeration period of HRT. The SBR was operated with an initial HRT of 5 days, including four operational steps, namely filling $(2 \mathrm{~h})$, aeration $(96 \mathrm{~h})$, settling $(21 \mathrm{~h})$, and decanting $(1 \mathrm{~h})$.

The full-scale yeast pretreatment systems were constructed before the conventional biological wastewater treatment (anaerobic, anoxic, and aerobic treatment) at the Wuxi Fortune Pharmaceutical Co. Ltd., Wuxi City, China. The full-scale wastewater treatment system, which has been in use since 2014, is shown in Figure 1. The yeast mixtures were transferred to four $140 \mathrm{~m}^{3}$ pretreatment reactors with floating balls used as the bio-carriers. The operational load was increased gradually until stable operation. More than $80 \mathrm{~m}^{3}$ of undiluted fermentation waste mother liquor was discharged into the yeast reactors every day. Operation conditions and evaluation indexes of the field experiment were based on the results of the pilot-scale test.

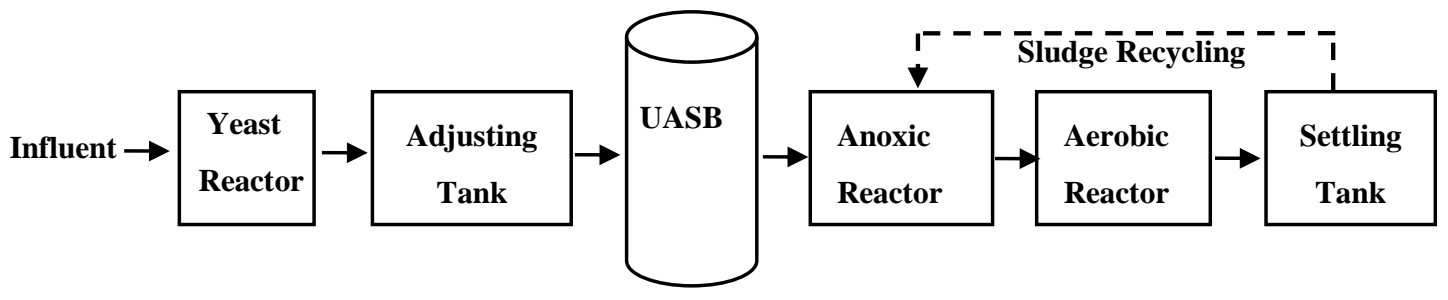

Figure 1. Full-scale fermentative antibiotic production wastewater treatment system.

\subsection{Sample Collection and Chemical Analyses}

The influent mixtures were collected from the antibiotic production workshop. For the pilot-scale test, water samples from the aeration periods and effluent were collected for 45 days (nine HRTs). Effluent mixtures from the full-scale reactors were sampled continuously for two weeks after a month-long adaptation period. SCOD, oil content, and settling velocity of the sludge were chosen as the main parameters to monitor the process ability. Water samples were centrifuged at $4000 \mathrm{r} / \mathrm{min}$ 
for $10 \mathrm{~min}$, and the resulting supernatant was passed through a 0.22 um filter before SCOD analyses. Oil content, SCOD, ammonia nitrogen, total nitrogen, and sulfate were determined according to the National Standard Methods of China [25]. SV was calculated as the volume percentage of sludge after standing for $30 \mathrm{~min}$ and the original mixture in the cylinder. Concentrations of paromomycin in wastewater were determined using ultra performance liquid chromatography tandem mass spectrometry (UPLC-MS/MS, Waters, Milford, MA, USA) [26]. DO and pH were detected with a portable $\mathrm{pH}$ meter (Mettler SG98-FK2, Zurich, Switzerland). All samples were analyzed for chemical properties in triplicate, and average values were reported.

All statistical analyses were performed using SPSS version 15.0. Pair-sample $t$-tests were used to assess whether the water quality was significantly different between influent and effluent samples based on $p$-values. A $p$-value of $<0.05$ was considered significant.

\subsection{Clone Library Analysis and $q P C R$}

Sludge samples were taken from the pilot and full-scale yeast reactors during stable field operation for microbial analysis. One milliliter of each sludge sample was centrifuged at $4000 \mathrm{r} / \mathrm{min}$ for $10 \mathrm{~min}$ at $4{ }^{\circ} \mathrm{C}$, and the resulting sediment was used for DNA extraction using a FastDNA ${ }^{\circledR}$ SPIN kit for soil (Qbiogene, Solon, OH, USA) per the manufacturer's instructions. For each sample, DNA was extracted in triplicate and pooled to avoid bias. Concentration and quality of extracted DNA were checked using a NanoDrop ND-1000 (Wilmington, DE, USA) and electrophoresis on 1\% (w/v) agarose gel.

For the clone library, $16 \mathrm{~S}$ rRNA genes were amplified with primers $27 \mathrm{~F}$ and $1492 \mathrm{R}$ for bacteria and 18S rRNA genes were amplified with primers NS1 (5'-GTAGTCATATGCTTGTCTC-3') and NS2 (5'-GGCTGCTGGCACCAGACTTGC-3') for eukarya $[27,28]$. The specific methods for clone libraries were based on our previous study [21]. Online sequence similarity searching was performed using the NCBI BLAST program and GenBank database. Calculation of coverage and classification of operational taxonomic units (OTUs, 97\% similarity) were carried out using DOTUR version 1.53. The 16S rRNA and 18S rRNA gene sequences obtained in this study were deposited in GenBank under accession numbers KU991824 to KU991825 and KX016000 to KX016005, respectively.

For the full-scale experiment samples, 16S rRNA and 18S rRNA genes were quantified with primers pairs 341F/534R[29] and FR1/FF390[30], respectively, using SYBR-Green real-time qPCR. The qPCR was run on an ABI7300 apparatus (ABI, USA), and was performed in a total volume of $25 \mu \mathrm{L}$ containing $1 \times$ Sybr Green I, $1 \times$ Dye (Takara), $200 \mathrm{nM}$ of each primer, BSA $0.5 \mathrm{mg} / \mathrm{mL}$, and $10 \mathrm{ng}$ of DNA template. The standard plasmids carrying target genes were obtained by TA clones and extracted using a TIANprep Mini Plasmid Kit (Tiangen, China). Triplicate real-time PCR assays were performed for decimally diluted standard plasmids and negative controls to obtain standard curves. Details on the temperature program, copy concentrations, and criteria for quality control of the quantitative results are discussed in our previous work [31]. Quality control of the qPCR for 16S rRNA and 18S rRNA genes is shown in Table 2. Specificity was assured by melting curves and gel electrophoresis.

Table 2. Quality control of quantitative polymerase chain reaction (qPCR) for $16 \mathrm{~S}$ rRNA and $18 \mathrm{~S}$ rRNA genes.

\begin{tabular}{ccccc}
\hline Genes & $\begin{array}{c}\text { Detection Limit of Method } \\
\text { (copies per ng DNA) }\end{array}$ & R2 & Slope & Efficiency * (\%) \\
\hline $\begin{array}{c}\text { Bacterial 16S } \\
\text { rRNA gene } \\
\begin{array}{c}\text { Eukaryal 18S } \\
\text { rRNA gene }\end{array}\end{array} \quad 2.7 \times 10^{2}$ & 0.99 & -3.24 & 103 \\
\hline \multicolumn{5}{c}{ * Efficiency $=\left(10^{-1 / \text { slope }}-1\right) \times 100 \%}$.
\end{tabular}




\section{Results and Discussion}

\subsection{Chemical Characteristics of Paromomycin Production Wastewater}

Details on the wastewater characteristics are summarized in Table 3. The fermentation antibiotic production waste mother liquor was characterized as acidic ( $\mathrm{pH} 5.26 \pm 0.4)$ with high organic loading (SCOD > 20,000 mg/L). The concentrations of paromomycin were at high levels $(9.63-12.57 \mathrm{mg} / \mathrm{L}$ ) in the influent. Soybean oil was added as the fermentative medium for paromomycin production, with high-strength oil residue found in the production wastewater $(13,800 \pm 38 \mathrm{mg} / \mathrm{L})$. Furthermore, the large amount of suspended solids (SS > 20,000 $\mathrm{mg} / \mathrm{L}$ ) with poor settling ability resulted in difficult solid-liquid separation of wastewater and fermentation residue. In a word, the fermentation antibiotic production wastewater is a big challenge for conventional biological treatment systems. Thus, effective pretreatment is a matter of great urgency.

Table 3. Quality characteristics of influent mixture.

\begin{tabular}{cc}
\hline Parameter & Influent Mixture \\
\hline Paromomycin (mg/L) & $10.85 \pm 1.8$ \\
SCOD $(\mathrm{mg} / \mathrm{L})$ & $28,000 \pm 56$ \\
Oil $(\mathrm{mg} / \mathrm{L})$ & $13,800 \pm 38$ \\
$\mathrm{SS}(\mathrm{mg} / \mathrm{L})$ & $20,030 \pm 45$ \\
$\mathrm{SV}(\%)$ & $91 \pm 3$ \\
$\mathrm{pH}$ & $5.26 \pm 0.4$ \\
$\mathrm{NH}_{4}{ }^{-}-\mathrm{N}(\mathrm{mg} / \mathrm{L})$ & $317.1 \pm 13$ \\
$\mathrm{TN}(\mathrm{mg} / \mathrm{L})$ & $921.9 \pm 22$ \\
$\mathrm{SO}_{4}{ }^{2-}(\mathrm{mg} / \mathrm{L})$ & $8700 \pm 36$ \\
\hline
\end{tabular}

\subsection{Performances of Pilot and Full-Scale Pretreatment Systems by Yeast}

The results of pre-experiment for antibiotic wastewater directly aerated without yeast mixture showed that the average removal rate of oil was only $8.0 \%$ and settling velocity was poor $(>70 \%)$. The treatment effect was not satisfactory if relying on wastewater wild microbiota alone, so bio-augmentation strategy of yeast became necessary.

Continuous monitoring was performed on the SBR in the pilot-scale system inoculated with isolated yeasts (Table 1) for 45 days. As shown in Figure 2, almost 90\% of oil was removed and sludge sedimentation performance ( $\left.\mathrm{SV}_{\text {effluent }}, 16.6 \%-21.3 \%\right)$ was obviously improved $(p<0.05)$. The daily SCOD removal rate, and SV were detected during the aeration period of an HRT, and showed that the SCOD removal rates and settling velocity on the third and fourth day of aeration were not improved significantly $(p>0.05)$. Through the pilot-scale experiments, the optimum aeration time was set at $72 \mathrm{~h}$, and an HRT of 4 days was used in the full-scale system to ensure treatment efficiency and reduce operation costs. 


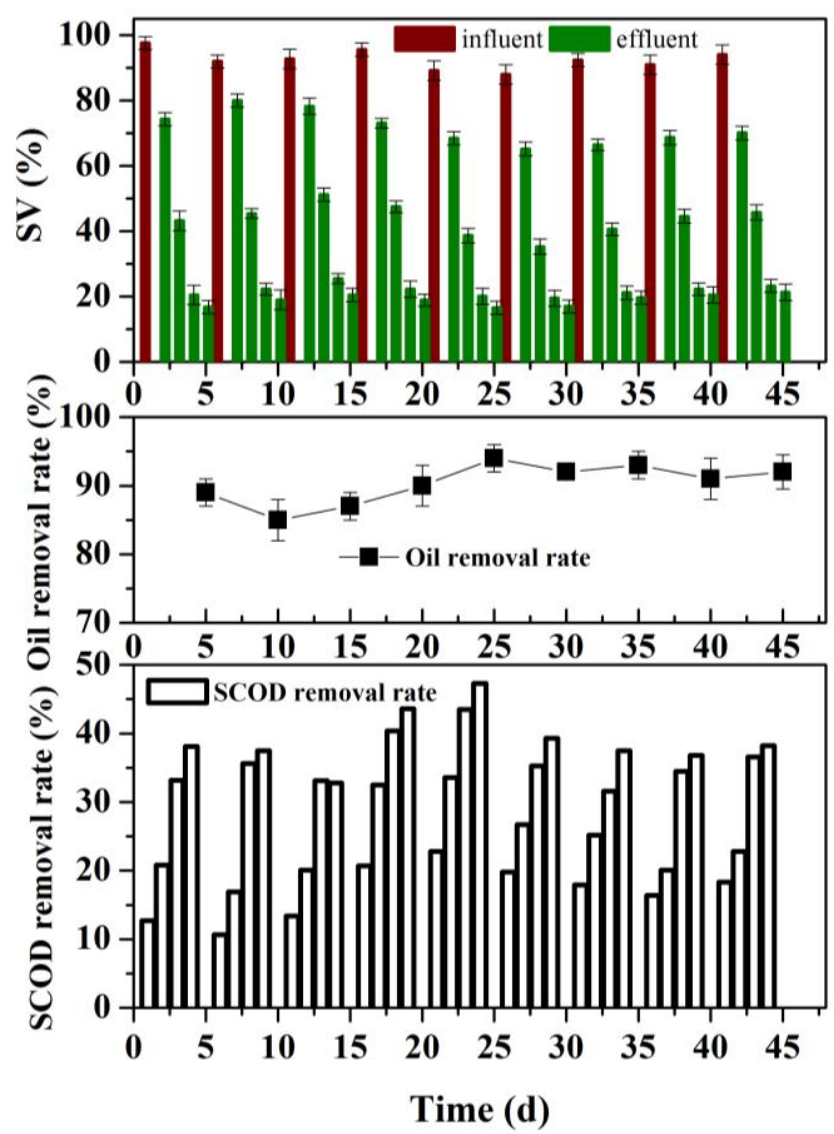

Figure 2. Performance of pilot-scale yeast sequencing batch reactor. SV of influent and effluent and oil removal rates were detected for 45 days (9 hydraulic retention times). Daily removal rate of SCOD and sludge settling velocity were detected for the aeration period.

Treatment performance of the full-scale system inoculated with isolated yeasts (Table 1) is shown in Figure 3. Oil removal rates were $61.4 \%-74.2 \%$, SV of effluent were $22.6 \%-32.0 \%$, and SCOD removal was maintained in the range of $26.7 \%-43.6 \%$. High oil removal rates and excellent sludge settling velocity were found in both pilot and full-scale yeast pretreatment systems. There was an obvious improvement in solid-liquid separation of fermentation residue and wastewater. However, SCOD removal efficiency was not high, which may have been affected by low DO in the yeast reactors [32]. The same trends of low DO $(<0.1 \mathrm{mg} / \mathrm{L})$ and acidification, with an average decrease in $\mathrm{pH}\left(\mathrm{pH}_{\text {influent }}=5, \mathrm{pH}_{\text {effluent }}=3\right)$, were found in the pilot and full-scale systems. The reason for the decrease in $\mathrm{pH}$ might be due to the degradation of long-chain fatty acids to short-chain organic acids. Overall, the yeast-based activated sludge processes for antibiotic production waste mother liquor achieved the desired targets. To our knowledge, it is the first time that yeast pretreatment system was designed and used successfully in engineering practice for oil-containing antibiotic production wastewater. The feasibility of employing fungi in antibiotic production wastewater had been proved. 


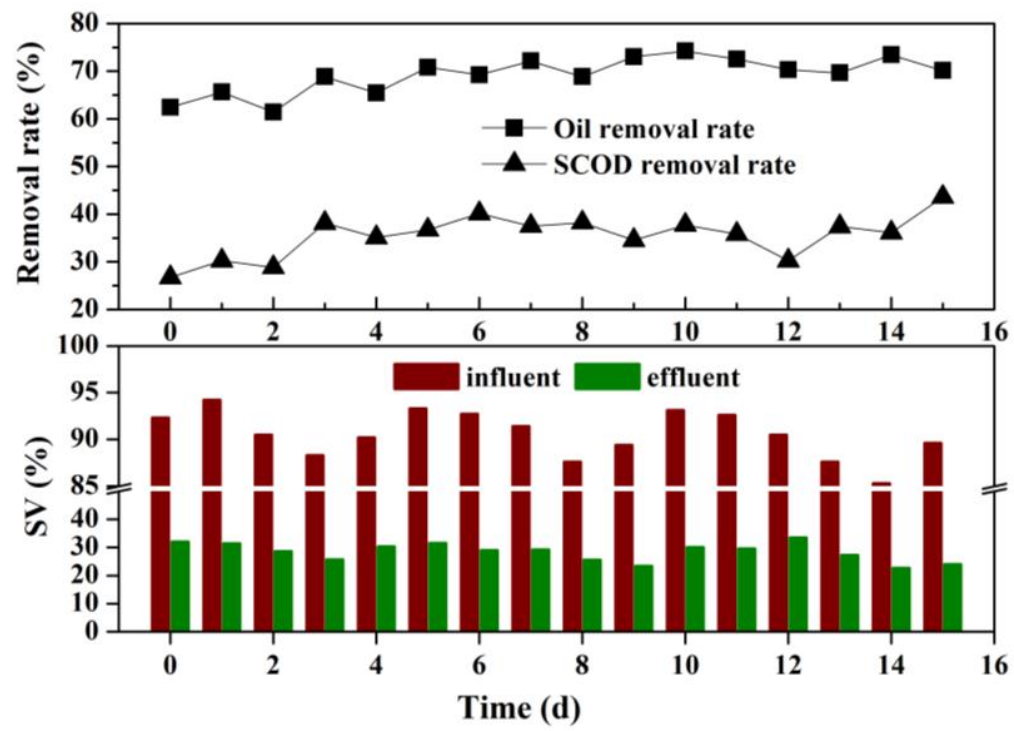

Figure 3. Performance of full-scale yeast pretreatment system. SV of influent and effluent and oil and SCOD removal rates were detected for 15 days successively during stable field operation.

\subsection{Composition of Eukarya and Bacteria in the Pilot and Full-Scale Systems}

Clone libraries of the 16S rRNA genes from the full-scale sludge samples and 18S rRNA genes from the pilot and full-scale sludge samples were constructed (Table 4). BLAST searches in the NCBI GenBank database confirmed that all sequenced clones matched known genes, with identities between $98 \%$ and $100 \%$. For the pilot-scale yeast system, a total of 105 sequenced $18 \mathrm{~S}$ rRNA gene clones were grouped into five OTUs. Pichia was dominant (53.3\%), followed by Candida $(24.8 \%)$ and Williopsis (18.1\%). Inoculated strain Trichosporon asahii disappeared during the pilot-scale process. However, clone library analyses revealed that fungal diversity was very low in the full-scale stage, with only Candida tropicalis detected individually. Our previous research showed that inoculated strain Candida tropicalis had the fastest growth rate and organic matter degradation rate of the studied yeast strains, as well as excellent cell emulsification ability and surface hydrophobicity, which made it the dominant strain in oil-heavy polluted wastewater [22].

Table 4. Analysis of eukaryal and bacterial clone libraries.

\begin{tabular}{ccccc}
\hline \multirow{2}{*}{ Clone Library } & \multirow{2}{*}{ Phylum } & Genus & \multicolumn{2}{c}{ No. of OTUs (No. of Clones) } \\
\cline { 3 - 5 } & & Pilot-scale & Full-scale \\
\hline \multirow{3}{*}{ Eukarya } & Ascomycota & Candida & $1(56)$ & - \\
& & Williopsis & $1(26)$ & $1(65)$ \\
& & Yarrowia & $1(4)$ & - \\
\hline Bacteria & Firmicutes & Lactobacillus & ND* & $2(72)$ \\
\hline & ND $^{*}$ : Not detected.
\end{tabular}

From the bacterial $16 \mathrm{~S}$ rRNA gene clone library of sludge samples from the full-scale system, 72 clones were selected and grouped into two OTUs. Only Lactobacillus brevis and Lactobacillus plantarum were found in the full-scale system. Oil was largely removed by yeast mixture, at the same time, long-chain fatty acids were degraded to short-chain organic acids, which caused the decrease in the $\mathrm{pH}$ of the wastewater. Generally, the optimum growth $\mathrm{pH}$ range for bacteria is $6.5-7.6$, and acidic $\mathrm{pH}$ is often believed to be toxic to bacteria [32]. Thus, with decreasing $\mathrm{pH}$, acidophilus organisms such as Lactobacillus sp. became the dominant bacteria. Above all, fermentation antibiotic production waste 
mother liquor with low $\mathrm{pH}$, high levels of residual antibiotics, and organic loads could greatly inhibit the diversity of microbial populations.

\subsection{Abundance of Fungal and Bacterial Genes in the Full-Scale System}

For biological augmentation systems, especially long-term systems, survival and dominant growth of fungi are key to ensuring treatment efficiency and system stability under the pressure of wastewater load and space competition with bacteria. In our study, the fungal/bacterial gene copy ratio was 14.87 , much higher than that observed in streptomycin and oxytetracycline production wastewater treatment activated sludge systems, and significantly higher than non-antibiotic (inosine) fermentation wastewater treatment plants [21,33] (Table 5), suggesting successful yeast colonization. Though further study is required, the high antibiotic residue in production waste mother liquor might have strongly affected the microbial community structure. This is understandable since antibiotics are designed to target bacteria. Previous reports have also shown that the existence of antibiotics can result in significant population shifts from bacteria to fungi [34-37]. Consequently, antibiotic wastewater is favorable for the growth of fungi. Another possibility is that wastewater quality was changed along with wastewater degraded by fungi, such as gradual reduction of $\mathrm{pH}$ value. The research has suggested that low $\mathrm{pH}$ can prevent bacterial contamination, and both acidic $\mathrm{pH}$ and high COD load are prerequisites for yeast to dominate the microbial community in continuous-mode activated sludge systems [32].

Table 5. Fungal and bacterial gene copy numbers of activated sludge samples from different wastewater treatment systems.

\begin{tabular}{cccccc}
\hline Genes & $\begin{array}{c}\text { Pretreatment } \\
\text { System for } \\
\text { Paromomycin } \\
\text { Wastewater } \\
\text { (copies/ng DNA) }\end{array}$ & $\begin{array}{c}\text { SBR for } \\
\text { Oxytetracycline } \\
\text { Mother Liquor [21] } \\
\text { (copies/uL DNA) }\end{array}$ & $\begin{array}{c}\text { Biological Contact } \\
\text { Oxidation Tanks for } \\
\text { Antibiotic-bearing } \\
\text { (mainly streptomycin) } \\
\text { Wastewater [32] } \\
\text { (copies/g) }\end{array}$ & $\begin{array}{c}\text { Oxidation Ditch for } \\
\text { Antibiotic-bearing } \\
\text { (mainly streptomycin) } \\
\text { Wastewater [32] } \\
\text { (copies/g) }\end{array}$ & $\begin{array}{c}\text { Inosine [21] } \\
\text { (copies/uL DNA) }\end{array}$ \\
\hline $\begin{array}{c}\text { Bacterial 16S } \\
\text { rRNA gene }\end{array}$ & $0.71 \times 10^{5}$ & $5.99 \times 10^{7}$ & $1.59 \times 10^{10}$ & $1.96 \times 10^{10}$ \\
$\begin{array}{c}\text { Eukaryal 18S } \\
\text { rRNA gene }\end{array}$ & $0.11 \times 10^{7}$ & $3.35 \times 10^{6}$ & $2.39 \times 10^{9}$ & $1.17 \times 10^{9}$ & $1.78 \times 10^{8}$ \\
Eukarya/Bacteria & 14.87 & 0.056 & 0.15 & 0.06 & $3.33 \times 10^{4}$ \\
\hline
\end{tabular}

Many studies have demonstrated that wastewater treatment microbial communities can maintain system stability by adjusting bacterial and eukaryal composition, with fungi abundant under the presence of antibiotics $[21,33]$. The highest number of yeasts with extracellular enzyme activities and phylogenetic distribution diversity was observed in antibiotic fermentation wastewater treatment systems [38]. Our study showed that yeast not only had excellent adaptation to antibiotic fermentation wastewater characterized by low $\mathrm{pH}$, high levels of residual antibiotics, and high organic loads, but also efficiently removed oil and promoted solid-liquid separation. This paper examined the feasibility of employing fungi in oil-containing antibiotic production wastewater pretreatment.

\section{Conclusions}

In this study, a yeast-based activated sludge process was established for antibiotic production wastewater pretreatment. After optimizing the operation parameters in a pilot-scale test, the yeast pretreatment system was applied in a pharmaceutical factory as a full-scale project, which removed most oil and promoted solid-liquid separation. Fungi were abundant (fungi: bacteria, 14.87) with the dominance of Candida tropicalis, indicating successful yeast colonization and less bacterial contamination. This study demonstrated the application potential of fungi in antibiotic production wastewater treatment. 
Acknowledgments: This work was supported by the National Natural Scientific Foundation of China (No. 21590814).

Author Contributions: Chunyan Wang conducted data collection and analysis, and contributed to the preparation of the manuscript; Ran Ding performed the wastewater treatment experiments; Yu Zhang and Yingxin Gao conceived and designed the experiments; Min Yang designed the experiments and analyzed the data.

Conflicts of Interest: The authors declare no conflicts of interest.

\section{References}

1. Ayar-Kayali, H.; Tarhan, L. Vancomycin antibiotic production and TCA-glyoxylate pathways depending on the glucose concentration in Amycolatopsis orientalis. Enzyme Microb. Technol. 2006, 38, 727-734. [CrossRef]

2. Chan, M.; Sim, T.S. Malate synthase from Streptomyces clavuligerus NRRL3585: Cloning, molecular characterization and its control by acetate. Microbiol. 1998, 144, 3229-3237. [CrossRef] [PubMed]

3. Environmental Protection Agency (EPA). Guides to Pollution Prevention: The Pharmaceutical Industry; EPA: Cincinnati, OH, USA, 1991.

4. LaPara, T.M.; Nakatsu, C.H.; Pantea, L.M.; Alleman, J.E. Aerobic biological treatment of a pharmaceutical wastewater: Effect of temperature on COD removal and bacterial community development. Water Res. 2001, 35, 4417-4425. [CrossRef]

5. Zhu, A.; Zhu, W.; Wu, Z.; Jing, Y. Recovery of clindamycin from fermentation wastewater with nanofiltration membranes. Water Res. 2003, 37, 3718-3732. [CrossRef]

6. Tekin, H.; Bilkay, O.; Ataberk, S.S.; Balta, T.H.; Ceribasi, I.H.; Sanin, F.D.; Dilek, F.B.; Yetis, U. Use of Fenton oxidation to improve the biodegradability of a pharmaceutical wastewater. J. Hazard. Mater. 2006, 136, 258-265. [CrossRef] [PubMed]

7. Achlesh, D.; Kannan, P. Pretreatment of synthetic dairy wastewater using the sophorolipid-producing yeast Candida bombicola. Appl. Biochem. Biotechnol. 2011, 163, 720-728.

8. Xing, Z.P.; Sun, D.Z. Treatment of antibiotic fermentation wastewater by combined polyferric sulfate coagulation, Fenton and sedimentation process. J. Hazard. Mater. 2009, 168, 1264-1268. [CrossRef] [PubMed]

9. Martinez, J.L. Environmental pollution by antibiotics and by antibiotic resistance determinants. Environ. Pollut. 2009, 157, 2893-2902. [CrossRef] [PubMed]

10. Munir, M.; Wong, K.; Xagoraraki, I. Release of antibiotic resistant bacteria and genes in the effluent and biosolids of five wastewater utilities in Michigan. Water Res. 2011, 45, 681-693. [CrossRef] [PubMed]

11. Hayet, D.; Abdeltif, A. Biodegradation by bioaugmentation of dairy wastewater by fungal consortium on a bioreactor lab-scale and on a pilot-scale. J. Environ. Sci. 2013, 25, 1906-1912.

12. Wang, X.X.; Zhao, Z.H.; Chang, T.S.; Liu, J.G. Yeast screening from avermectins wastewater and investigation on the ability of its fermentation. Bioproc. Biosyst. Eng. 2011, 34, 1127-1132. [CrossRef] [PubMed]

13. Tondee, T.; Sirianuntapiboon, S.; Ohmomo, S. Decolorization of molasses wastewater by yeast strain, Issatchenkia orientalis No. SF9-246. Bioresour. Technol. 2008, 99, 5511-5519. [CrossRef] [PubMed]

14. Zhang, Y.M.; Rittmann, B.E.; Wang, J.L.; Sheng, Y.H.; Yu, J.T.; Shi, H.C.; Qian, Y. High-carbohydrate wastewater treatment by IAL-CHS with immobilized Candida tropicalis. Process Biochem. 2005, 40, 857-863. [CrossRef]

15. Coimbra, C.D.; Rufino, R.D.; Luna, J.M.; Sarubbo, L.A. Studies of the cell surface properties of Candida species and relation to the production of biosurfactants for environmental applications. Curr. Microbiol. 2009, 58, 245-251. [CrossRef] [PubMed]

16. Sugimori, D. Edible oil degradation by using yeast coculture of Rhodotorula pacifica ST3411 and Cryptococcus laurentii ST3412. Appl. Microbiol. Biotechnol. 2009, 82, 351-357. [CrossRef] [PubMed]

17. Sarubbo, L.A.; Farias, C.B.B.; Campos-Takaki, G.M. Co-Utilization of Canola Oil and Glucose on the Production of a Surfactant by Candida lipolytica. Curr. Microbiol. 2007, 54, 68-73. [CrossRef] [PubMed]

18. Wu, L.; Ge, G.; Wan, J.B. Biodegradation of oil wastewater by free and immobilized Yarrowia lipolytica W29. J. Environ. Sci. 2009, 21, 237-242. [CrossRef]

19. Manuela, T.; Maurizio, C. Use of Pichia fermentans and Candida sp. strains for the biological treatment of stored olive mill wastewater. Biotechnol. Lett. 2011, 33, 2385-2390.

20. Yang, M.; Zheng, S. Pollutant removal-oriented yeast biomass production from high-organic-strength industrial wastewater: A review. Biomass Bioenergy 2014, 64, 356-362. [CrossRef] 
21. Zhang, Y.; Xie, J.P.; Liu, M.M.; Tian, Z.; He, Z.L.; van Nostrand, J.D.; Ren, L.R.; Zhou, J.Z.; Yang, M. Microbial community functional structure in response to antibiotics in pharmaceutical wastewater treatment systems. Wat. Res. 2013, 47, 6298-6308. [CrossRef] [PubMed]

22. Lv, W.Z.; Hesham, A.E.L.; Zhang, Y.; Liu, X.C.; Yang, M. Impacts of cell surface characteristics on population dynamics in a sequencing batch yeast reactor treating vegetable oil-containing wastewater. Appl. Microbiol. Biotechnol. 2011, 90, 1785-1793. [CrossRef] [PubMed]

23. Hesham, A.E.L.; Wang, Z.Y.; Zhang, Y.; Zhang, J.; Lv, W.Z.; Yang, M. Isolation and identification of a yeast strain capable of degrading four and five ring aromatic hydrocarbons. Ann. Microbiol. 2006, 56, 109-112. [CrossRef]

24. Zheng, S.K.; Yang, M.; Li, P.R. Seed yeast cultivation for salad oil manufacturing wastewater treatment. J. Environ. Sci. 2002, 14, 39-43.

25. Wei, F.S. Monitoring and Analysis Methods of Water and Wastewater; Chinese Environmental Sciences Publishment: Beijing, China, 2002.

26. Róna, K.; Klausz, G.; Keller, E.; Szakay, M.; Laczay, P.; Shem-Tov, M.; Székely-Körmöczy, P. Determination of paromomycin residues in turkey tissues by liquid chromatography/mass spectrometry. J. Chromatogr. B 2009, 877, 3792-3798. [CrossRef] [PubMed]

27. Polz, M.F.; Harbison, C.; Cavanaugh, C.M. Diversity and heterogeneity of epibiotic bacterial communities on the marine nematode Eubostrichus dianae. Appl. Environ. Microbiol. 1999, 65, 4271-4275. [PubMed]

28. O’Brien, H.E.; Parrent, J.L.; Jackson, J.A.; Moncalvo, J.M.; Vilgalys, R. Fungal community analysis by large-scale sequencing of environmental samples. Appl. Environ. Microbiol. 2005, 71, 5544-5550.

29. Koike, S.; Krapac, I.G.; Oliver, H.D. Monitoring and source tracking of tetracycline resistance genes in lagoons and groundwater adjacent to swine production facilities over a 3-year period. Appl. Environ. Microbiol. 2007, 73, 4813-4823. [CrossRef] [PubMed]

30. Prévost-bouré, N.C.; Christen, R.; Dequiedt, S.; Mougel, C.; Leliévre, M.; Jolivet, C.; Shahbazkia, H.R.; Guillou, L.; Dominique, A.; Lionel, R. Validation and application of a PCR primer set to quantify fungal communities in the soil environment by real-time quantitative PCR. PLOS ONE 2011. [CrossRef]

31. Liu, M.; Zhang, Y.; Yang, M.; Tian, Z.; Ren, L.; Zhang, S. Abundance and distribution of tetracycline resistance genes and mobile elements in an oxytetracycline production wastewater treatment system. Environ. Sci. Technol. 2012, 46, 7551-7557. [CrossRef] [PubMed]

32. Zheng, S.K.; Zhang, Y.; Tong, T.; Cui, C.; Sun, J. Dominance of yeast in activated sludge under acidic pH and high organic loading. Biochem. Eng. J. 2010, 52, 282-288. [CrossRef]

33. Yang, S.F.; Li, X.Y.; Yu, H.Q. Formation and characterisation of fungal and bacterial granules under different feeding alkalinity and $\mathrm{pH}$ conditions. Process Biochem. 2008, 43, 8-14. [CrossRef]

34. Deng, Y.Q.; Zhang, Y.; Gao, Y.X.; Li, D.; Liu, R.Y.; Liu, M.M.; Zhang, H.; Hu, B.; Yu, T.; Yang, M. Microbial community compositional analysis for series reactors treating high level antibiotic wastewater. Environ. Sci. Technol. 2012, 46, 795-801. [CrossRef] [PubMed]

35. Bundschuh, M.; Hann, T.; Gessner, M.O.; Schulz, R. Antibiotics as a chemical stressor affecting an aquatic decomposer-detritivore system. Environ. Toxicol. Chem. 2009, 28, 197-203. [CrossRef] [PubMed]

36. Demoling, L.A.; Baath, E.; Greve, G.; Wouterse, M.; Schmitt, H. Effects of sulfamethoxazole on soil microbial communities after adding substrate. Soil Biol. Biochem. 2009, 41, 840-848. [CrossRef]

37. Zielezny, Y.; Groeneweg, J.; Vereecken, H.; Tappe, W. Impact of sulfadiazine and chlorotetracycline on soil bacterial community structure and respiratory activity. Soil Biol. Biochem. 2006, 38, 2372-2380. [CrossRef]

38. Yang, Q.X.; Zhang, H.; Li, X.L.; Wang, Z.; Xu, Y.; Ren, S.W.; Chen, X.Y.; Xu, Y.Y.; Hao, H.X.; Wang, H.L. Extracellular enzyme production and phylogenetic distribution of yeasts in wastewater treatment systems. Bioresour. Technol. 2013, 129, 264-273. [CrossRef] [PubMed]

(C) 2017 by the authors. Licensee MDPI, Basel, Switzerland. This article is an open access article distributed under the terms and conditions of the Creative Commons Attribution (CC BY) license (http:/ / creativecommons.org/licenses/by/4.0/). 